Bangladesh J. Bot. 49(3): 557-566, 2020 (September)

\title{
GENOTOXICITY AND ANTIMICROBIAL ACTIVITY OF MYRTUS COMMUNIS L., ZIZIPHUS SPINA-CHRISTI (L.) WILLD AND CASSIA ANGUSTIFOLIA VAHL EXTRACTS
}

\author{
Amina A Hassan* and Gehan O Abd-Elaziz \\ Department of Biology, Faculty of Science, King Faisal University, Saudi Arabia
}

Keywords: Genotoxicity, Prophage induction, Antimicrobial activity, Inhibition zone

\begin{abstract}
Genotoxicity and antimicrobial activity of the leaf extract of Myrtus communis, Ziziphus spina-christi and Cassia angustifolia plants were evaluated. The prophage induction assay was used to test the genotoxicity. The results showed that, no fold increase in Pfu/ml over the spontaneous release for F116 and R3 phages, so these results indicated that Myrtus communis, Ziziphus spina-christi and Cassia angustifolia leaves extract did not have genotoxic effect, so they can be used as antimutagen. On the other hand, Myrtus communis and Ziziphus spina-christi showed strong antimicrobial activity against all tested microbes. The antimicrobial effect increased by the increase of the concentration. While Cassia angustifolia leaves extract showed moderate antimicrobial activity against some strains. The results of antimicrobial activity suggest that these plant extracts have cytotoxic effect.
\end{abstract}

\section{Introduction}

Millions of people in the world use plants as spices or food flavors. They also use them for healing purposes as part of traditional medicine. Many local people in Al-Ahsa, Saudi Arabia are dependent on herb trading and medicinal plants as a means of livelihood and income generation. Medicinal plants are popular with people of developing countries for health care because of compatibility with human body, better cultural acceptability and fewer side effects (Amal et al. 2010). The traditional medicine uses some common plants for treatment some common diseases such as diabetes, diarrhea, allergies, headache, fever, arthritis, eye diseases, skin diseases, nervous disorders and stomachache. Myrtus communisis as very important aromatic medicinal plants because of the high essential oil contents of its leaves, flowers and fruit glands. Myrtus communis were used for its antioxidant, antiseptic, antimutagen, anti-inflammation and insecticide activity. In folk medicine leaves and decoction of fruits are used in treatment of cough, oral diseases and hypoglycaemic stomach pain (Touaibia 2015). In Saudi Arabian folk medicine, the leaves of Zizyphus spina-christi are used to treat fever, sex diseases, some skin diseases, sores, gonorrhoea, and wound healing. The fresh fruits and bark are used as a body wash and healing of newly emerging wounds while the fruits are used for the treatment of dysentery (Al-Mutairi et al. 2016). The Cassia species members are rich sources of polysaccharides, polyphenols, flavonoids and anthraquinone derivatives, which exhibit antioxidant, antimutagenic, anti-inflammatory, antiplasmodial, and anticancer activities. They are also widely used for the treatment of wounds, scabies, eczema, gastrointestinal disorders and skin diseases.

On the other hand, green plants contain substances that may be mutagenic and carcinogenic, but there is little information on the biological effects of these compounds, so it is important to assay the genotoxic and cytotoxic effects of phyto-therapeutic substances (Silva et al. 2012). The prophage induction is a short-term test performed with lysogenic strains allowing the assessment

*Author for correspondence: <aahassan@kfu.edu.sa〉. 
one of SOS function, so it is used to evaluate the mutagenic effects of substances. When bacterial cells are exposed to DNA damaging agents, DNA replication is repressed, this leads to prophage to enter the lytic cycle as an expression of SOS response (Silva et al. 2012). Various evidences indicated that, prophage induction is a broader genetic endpoint than any other bacterial assay. It is a sensitive test were addition or no addition of any activator substance will not change the results. Sometime, the mutagenic evaluation of substances may escape when tested with Ames test, the mutagenic activity using Salmonella was negative, whereas the prophage induction assay was positive.

The plants contain many biologically important phytochemicals and bioactive compounds such as peptides, cyclopeptides, flavonoids, sterols, tannins, alkaloids, betulinic acid and glycosides (Ads et al. 2017). Many plants were used to treat infectious diseases, so it is considered as important new source of antimicrobial agents (Bereksi et al. 2018). The excessive use of antibiotics in clinical medicine, agriculture, and veterinary is very dangerous to the environment and therefore to humans as it promotes the spread of antibiotic resistant genes between microbes, which leads to the creation of a clan of antibiotic-resistant microbes. This is due to the lack of effectiveness of antibiotics in the treatment of pathogenic microbes. So, it is necessary to search for new sources of antimicrobial agents especially among plants which contain natural products and may contain medical compounds that act as antimicrobial agents. Therefore, the aim of this study was to evaluate genotoxicity and the antimicrobial activities of plant extracts of Myrtus communis, Ziziyphus spina-christi and Cassia angustifolia that are used in traditional medicine in Al-Ahsa, Saudi Arabia.

\section{Materials and Methods}

The nutrient agar and nutrient broth media were used. Soft agar $(0.7 \% \mathrm{w} / \mathrm{v}$ agar $)$ was prepared in distilled water and kept at $45^{\circ} \mathrm{C}$ on water bath. Phosphate buffer was prepared from $1 / 15 \mathrm{M}$ $\mathrm{KH}_{2} \mathrm{PO}_{4}$ and $1 / 15 \mathrm{M} \mathrm{Na} 2 \mathrm{HPO}_{4} .2 \mathrm{H}_{2} \mathrm{O}$. Streptomycin was added to the media after autoclaving as sterilized solutions, it was sterilized by filtration through $0.2 \mu \mathrm{m}$ filter membrane. Whatman membrane filter, diameter $25 \mathrm{~mm}$, pore size $0.2 \mu \mathrm{m}$ was used.

The generalized transducing F116 phage and the original host bacterial strains of Pseudomonas aeruginosa PAO1, PU21 and lysogenic MAM2, were obtained from M. Day, University of Wales, Cardiff, UK. Other bacterial (Bacillus thuringiensis host strain of R3 temperate phage and Staphylococcus aureus), fungal (Rhodotorula spp.) strains were obtained from Microbial Genetics Lab., Faculty of Agriculture, Zagazig University, Egypt.

Three species of plants widely used by local people are Myrtus communis, Ziziyphus spinachristi and Cassia angustifolia which were collected from local market. The dried leaves were ground and briefly, $100 \mathrm{~g}$ of plant sample was extracted with $500 \mathrm{ml} 95 \%$ ethanol at room temperature for $48 \mathrm{hrs}$ in order to extract the bioactive compounds (Nkafamiya et al. 2013). The ethanol crude extract products were poured into dishes and kept in dry oven at $40^{\circ} \mathrm{C}$ for 3 - 4 days until the extract materials were concentrated (Romha et al. 2018). The extracts were weighted, labeled and stored in the refrigerator at $4^{\circ} \mathrm{C}$ for further analysis.

The combination between methods of Siddiqui et al. (2011) and Silva et al. (2012) with some modifications was used for the prophage induction test. The lysogenic of MAM2 and Bt10 bacterial strains were grown to exponential phase $\left(1.6 \times 10^{8}\right)$, centrifuged and resuspended in $10 \mathrm{ml}$ of phosphate buffer solution. The test extract samples at different concentrations $(5,15$ and 30 $\mathrm{mg} / \mathrm{ml}$ ) at $30^{\circ} \mathrm{C}$ for $3 \mathrm{hrs}$ were treated. The treated cells were again centrifuged, washed and suspended in nutrient broth and incubated at $30^{\circ} \mathrm{C}$ for $3 \mathrm{hrs}$, centrifuged at $5000 \mathrm{rpm}$ for $30 \mathrm{~min}$ and filtrated through $0.2 \mu \mathrm{m}$ filter membrane (Whatman). The supernatant was collected, diluted 
and plated with indicator cells. The number of plaques were scored using phage titration test, the plaque forming units $(\mathrm{Pfu} / \mathrm{ml})$ were calculated for each concentration. Ethylmethane sulfonate (EMS) was used as a positive control and ascorbic acid (vitamin C) as a negative control. The phage was propagated using the plate method on its bacterial host, $0.1 \mathrm{ml}$ of phage diluted sample was mixed with $0.1 \mathrm{ml}$ of host suspension $\left(10^{8} \mathrm{CFU} / \mathrm{ml}\right)$ in NB broth in a sterile tube and incubated for $15-20 \mathrm{~min}$ at room temperature to facilitate adsorption of the phage to the host cells. The mixture was added to 3 - $5 \mathrm{ml}$ of soft layer agar cooled to $45^{\circ} \mathrm{C}$ and well mixed. Then, poured over the NA Agar plate and sit for $15 \mathrm{~min}$ at room temperature. The plates were incubated for $18 \mathrm{hrs}$ at $30^{\circ} \mathrm{C}$. Clear areas of lytic plaques (Plaque forming unit, Pfu/ml) was counted. A plate showing confluent plaques was used to prepare a concentrated phage suspension by overlaying with $5 \mathrm{ml}$ of NB broth. The over layer medium containing the phage was decanted and filtered through a 0.2 $\mu \mathrm{m}$ filter membrane. The filtrate was used as a phage stock solution. Several dilutions of phage solution were made (Behravan et al. 2011).

Antibacterial activities of Myrtus communis, Ziziyphus spina-christi and Cassia angustifolia extracts were investigated by disc diffusion method. The test suspension which was approximately $1.3 \times 10^{6}$ colony forming units $(\mathrm{CFU} / \mathrm{ml})$ of bacteria were spread on the agar plates. The tests were conducted with three extract concentrations 5,15 and $30 \mathrm{mg} / \mathrm{ml}$ by dissolving in distilled water. Sterile filter paper discs $(6.0 \mathrm{~mm})$ were saturated with selected concentration of used extracts. The discs were placed on the surface of the inoculated medium and left for $30 \mathrm{~min}$ at room temperature for compound diffusion (Belmimoun et al. 2016). Negative controls were performed using distilled water. Positive controls were performed using $5 \mathrm{mg} / \mathrm{ml}$ streptomycin. The plates were incubated at $30^{\circ} \mathrm{C}$, the growth inhibition zones around the discs were estimated after incubation time (18 - $24 \mathrm{hrs})$. The sensitivity of the bacterial strains to the extracts was determined by measuring the size of inhibitory zones around the discs (including the diameter of disc). The inhibition zone diameters was as follows: negative $=0 \mathrm{~mm}$, weak $=1-4 \mathrm{~mm}$, moderate $=5-10$ $\mathrm{mm}$, strong $=10-15 \mathrm{~mm}$, very strong $=\geq 16 \mathrm{~mm}$ (Amal et al. 2010). Values less than $8 \mathrm{~mm}$ were considered as not active but $14 \mathrm{~mm}$ or greater was considered as high antibacterial activity (Belmimoun et al. 2016). All the experiments were conducted in triplicate to minimize test error. The same procedure was followed with fungus. Bacterial host strains were prepared by directly transferring one colony from an agar plate to $5 \mathrm{ml} \mathrm{NB}$ and incubation at $30^{\circ} \mathrm{C}$ in shaker incubator for one hr. The $0.5 \mathrm{ml}$ of phage was added to $0.5 \mathrm{ml}$ of selected concentrations of plant extract. The mixture was left at room temperature for $30 \mathrm{~min}$. 0.5 of previously bacterial host suspension was mixed with $5 \mathrm{ml}$ soft agar $(0.7 \%)$. The mixture of phage and extract were added to soft agar and mixed, Then, the soft-agar medium was poured on nutrient agar plate and left to solidify. The plates were incubated inverted at $30^{\circ} \mathrm{C}$ for $12-16 \mathrm{hrs}$. Antibacteriophage activity was then considered as the absence of plaque formation in comparison with the control, which had distilled water instead of the plant extract (Behravan et al. 2011).

Each experiment was repeated in triplicate and the means \pm standard error from the absolute data were calculated.

\section{Results and Discussion}

Short-term experiments were conducted to identify potential genotoxicty of Myrtus communis, Ziziyphus spina-christi and Cassia angustifolia which were purchased from Saudi Arabia markets as medicinal plants. Data in Tables 1 and 2 summarize the results of prophage induction; the used concentrations $(5,15,30 \mathrm{mg} / \mathrm{ml})$ did not show increase in the prophage induction when compared with control. Mutagenic index indicated no fold increase in Pfu/ml over the spontaneous release of phage from the lysogenic strains. So, the tested plant extracts do not 
possess genotoxic effect. According to DeMarini et al. (1990), the positive response of any compound is recommended to be corresponding to a three-fold increase in Pfu/ml over the spontaneous background release of the lysogenic strain.

Table 1. Prophage F116 induction from lysogenic strain by Myrtus communis, Ziziyphus spina-christi and Cassia angustifolia extracts.

\begin{tabular}{lcccc}
\hline \multirow{2}{*}{ Plant extract } & $\begin{array}{c}\text { Concentration } \\
(\mathrm{mg} / \mathrm{ml})\end{array}$ & $\begin{array}{c}\text { Pfu/ml } \\
\left(10^{7}\right)\end{array}$ & $\begin{array}{c}\text { Mutagenic index } \\
(\text { fold increase) }\end{array}$ & $\begin{array}{c}\text { Mutagenic } \\
\text { response }\end{array}$ \\
\cline { 3 - 5 } & & 0 & - & - \\
Myrtus communis & 5 & 0 & - & - \\
& 15 & 0 & - & - \\
Ziziyphus spina-christi & 30 & $3.6 \pm 0.12$ & 1.71 & - \\
& 5 & $1.41 \pm 0.04$ & 0.67 & - \\
Cassia angustifolia & 15 & 0 & 0 & - \\
& 30 & $6.9 \pm 0.31$ & 3.28 & - \\
Control (spontaneous) & 5 & $4.3 \pm 0.23$ & 2.04 & - \\
Negative control (ascorbic acid 1\%) & 15 & $2.5 \pm 0.03$ & 1.19 & - \\
Positive control (EMS 1\%) & 30 & $2.1 \pm 0.02$ & 1.0 & - \\
\hline
\end{tabular}

Table 2. Prophage R3 induction from lysogenic strain by Myrtus communis, Ziziyphus spina-christi and Cassia angustifolia extracts.

\begin{tabular}{lcccc}
\hline \multirow{2}{*}{ Plant extract } & $\begin{array}{c}\text { Concentration } \\
(\mathrm{mg} / \mathrm{ml})\end{array}$ & $\begin{array}{c}\text { Pfu/ml } \\
\left(10^{7}\right)\end{array}$ & $\begin{array}{c}\text { Mutagenic index } \\
\text { (fold increase) }\end{array}$ & $\begin{array}{c}\text { Mutagenic } \\
\text { response }\end{array}$ \\
\cline { 3 - 5 } Myrtus communis & 5 & 0 & - & - \\
& 15 & 0 & - & - \\
Ziziyphus spina-christi & 30 & 0 & - & - \\
& 5 & $0.02 \pm 0.01$ & 0.015 & - \\
Cassia angustifolia & 15 & 0 & - & - \\
& 30 & 0 & - & - \\
Control (spontaneous) & 5 & $0.12 \pm 0.01$ & 0.092 & - \\
Negative control (ascorbic acid 1\%) & 15 & $0.07 \pm 0.01$ & 0.004 & - \\
Positive control (EMS 1\%) & 30 & 0.050 .11 & 0.038 & - \\
\hline
\end{tabular}

$-<3=$ Non mutagen, $+=3-10=$ Mutagen, $++=11-19=$ Effective mutagen, $+++=>19=$ Very effective mutagen. 
SOS induction agents able to create DNA damages and block DNA replication, one of the manifestations of SOS functions is prophage induction and entry in the lytic cycle (Silva et al. 2012). In bacteria, repression of DNA replication or DNA damage triggers types of functions called the SOS response. The SOS response in E. coli involves the RecA, LexA proteins, a repressor and an inducer. When DNA is damaged, a single-stranded DNA is produced and this possibly activates the RecA protein to a form catalyze the cleavage of LexA protein. The LexA protein represses the genes involved in repair function. Therefore, cleavage of LexA protein under SOS conditions has enhanced expression of the lexA+ and recA+ genes. The role of recA+, lexA+ genes in the SOS repair of E. coli K-12 is well documented (Siddiqui et al. 2011). The bacteriophages are also cleaved under the same conditions, leading to the prophage induction in lysogen and entering in lytic cycle. Generally, the compounds that are genotoxic to higher eukaryotes also capable of inducing the SOS response in bacteria (Siddiqui et al. 2011). Prophage induction and SOS response occur by a variety of mechanisms and involves a number of classes of genetic damage, including alkylation, strand scissions, oxidation and cross-links. DNA strand breaks are inducer of prophage from lysogen. Siddiqui et al. (2011) evaluated the genotoxicity of certain water bodies by prophage lambda induction in the lysogen defective mutants of Escherichia coli and the plasmid nicking assay. They recorded a significant level of phage induction in case of industrial wastewater followed by that in river and groundwater samples. Silva et al. (2012) used prophage induction assay to assess genotoxic effect of Duguetia furfuracea extract. Their results proved that there was an increase of prophage $\lambda$ induction with the dose $1 \mathrm{mg} / \mathrm{ml}$, but the high doses $(2,5,10 \mathrm{mg} / \mathrm{ml})$ caused a decrease of the prophage induction.

Table 3. Inhibition zone of ethanolic extracts of Myrtus communis, Ziziyphus spina-christi and Cassia angustifolia against bacteria.

\begin{tabular}{|c|c|c|c|c|c|c|c|c|}
\hline \multirow[t]{2}{*}{$\begin{array}{l}\text { Plant extract } \\
\text { /Conc. } \\
(\mathrm{mg} / \mathrm{ml})\end{array}$} & \multicolumn{3}{|c|}{$\begin{array}{c}\text { Bacillus } \\
\text { thuringiensis }\end{array}$} & \multicolumn{2}{|c|}{$\begin{array}{c}\text { Diameter }(\mathrm{nm}) \pm \text { S.E. } \\
\text { Staphylococcus } \\
\text { aureus }\end{array}$} & \multicolumn{3}{|c|}{$\begin{array}{c}\text { Pseudomonas } \\
\text { aeruginosa }\end{array}$} \\
\hline & Bt3 & $\mathrm{Bt} 8$ & HD1 & SM10 & SM12 & PAO1 & PU21 & MAM2 \\
\hline \multicolumn{9}{|c|}{ Myrtus communis } \\
\hline 5 & $9 \pm 0.21$ & $8 \pm 0.13$ & $7 \pm 0.21$ & $8 \pm 0.13$ & $10 \pm 0.33$ & $6 \pm 0.40$ & $8 \pm 0.21$ & $7 \pm 0.13$ \\
\hline 15 & $15 \pm 0.43$ & $15 \pm 0.08$ & $9 \pm 0.89$ & $10 \pm 0.23$ & $12 \pm 0.33$ & $8 \pm 0.22$ & $13 \pm 0.23$ & $10 \pm 0.43$ \\
\hline 30 & $20 \pm 0.98$ & $20 \pm 0.23$ & $15 \pm 0.91$ & $12 \pm 0.40$ & $20 \pm 0.67$ & $17 \pm 0.40$ & $18 \pm 0.11$ & $18 \pm 0.35$ \\
\hline \multicolumn{9}{|c|}{ Ziziyphus spina-christi } \\
\hline 5 & $7 \pm 0.13$ & $8 \pm 0.13$ & 0 & $8 \pm 0.21$ & $6 \pm 0.40$ & $6 \pm 0.40$ & $7 \pm 0.14$ & $8 \pm 0.11$ \\
\hline 15 & $11 \pm 0.15$ & $12 \pm 0.78$ & $8 \pm 0.22$ & $10 \pm 0.33$ & $10 \pm 0.23$ & $10 \pm 0.36$ & $10 \pm 0.27$ & $10 \pm 0.23$ \\
\hline 30 & $14 \pm 0.24$ & $15 \pm 0.53$ & $12 \pm 0.33$ & $15 \pm 0.65$ & $17 \pm 0.28$ & $16 \pm 0.65$ & $15 \pm 0.76$ & $13 \pm 0.78$ \\
\hline \multicolumn{9}{|c|}{ Cassia angustifolia } \\
\hline 5 & 0 & 0 & 0 & 0 & 0 & 0 & $8 \pm 0.13$ & 0 \\
\hline 15 & $7 \pm 0.15$ & 0 & 0 & $7 \pm 0.15$ & 0 & 0 & $10 \pm 0.23$ & 0 \\
\hline 30 & $12 \pm 0.33$ & $8 \pm 0.13$ & 0 & $10 \pm 0.45$ & 0 & 0 & $12 \pm 0.32$ & 0 \\
\hline
\end{tabular}

Antibacterial activity of Myrtus communis, Ziziyphus spina-christi and Cassia angustifolia were tested against Bacillus thuringiensis, Staphylococcus aureus and Pseudomonas aeruginosa strains using disc diffusion method. Bacterial strains were subjected to $5 \mathrm{mg} / \mathrm{ml}$ streptomycin to 
obtain streptomycin resistant mutants and bacterial cell mutants were tested with ethanolic plant extracts. The results obtained in this study are presented in Table 3 and Figs 1,2 . Average diameter of inhibition zone was 0 to $20 \mathrm{~mm}$ at used concentrations (5, 15 and $30 \mathrm{mg} / \mathrm{ml}$ ). Myrtus communis and Ziziyphus spina-christi were highly efficient against all used bacterial strains at 30 $\mathrm{mg} / \mathrm{ml}$ (Fig. 1). The maximum inhibition zone $(20 \mathrm{~mm}$ ) was found in $30 \mathrm{mg} / \mathrm{ml}$ of Myrtus communis with Bacillus thuringiensis and Staphylococcus aureus followed by Pseudomonas aeruginosa $(18 \mathrm{~mm})$. The results of antibacterial activity of Myrtus communis agree with those reported by Behbahani et al. (2016), Jerbi et al. (2016), Ads et al. (2017) and Alyousef et al. (2018) but vary in the active concentration. While, Taheri et al. (2013) showed that Myrtus communis has no effect on Pseudomonas aeruginosa. The discs containing $5 \mathrm{mg} / \mathrm{ml}$ showed the lowest inhibitory zones $(6-10 \mathrm{~mm})$. Ziziyphus spina-christi extract was less efficient than Myrtus communis, the highest inhibition zone diameter of Ziziyphus spina-christi was $17 \mathrm{~mm}(30 \mathrm{mg} / \mathrm{ml})$ against Staphylococcus aureus followed by Pseudomonas aeruginosa $(16 \mathrm{~mm})$, while Bacillus

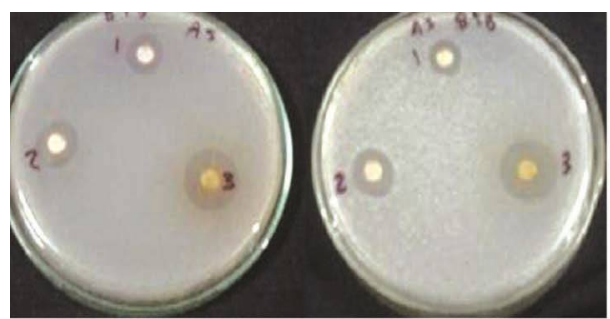

Bacillus thuringiensis

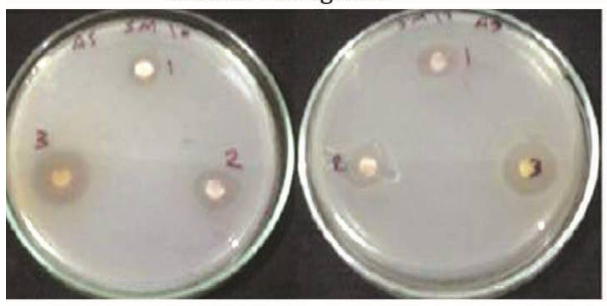

Staphylococcus aurous

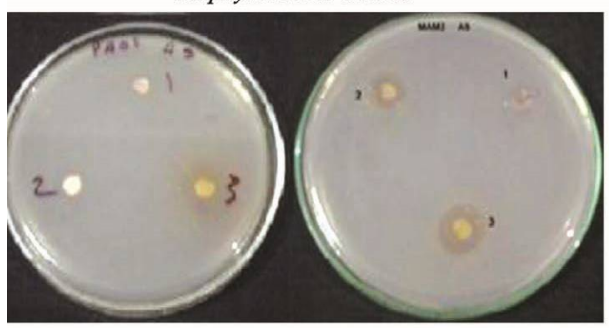

Pseudomonas aeruginosa

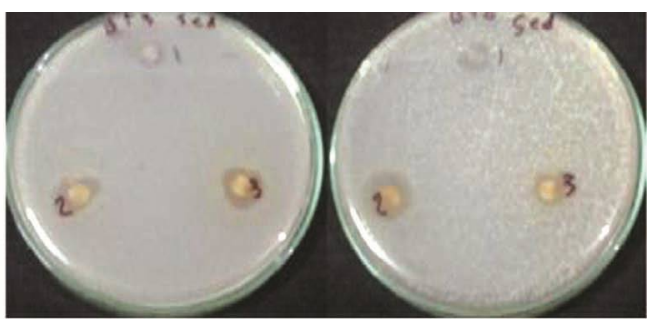

Bacillus thuringiensis

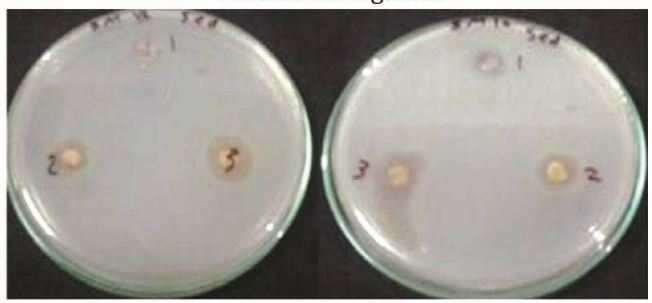

Staphylococcus aurous

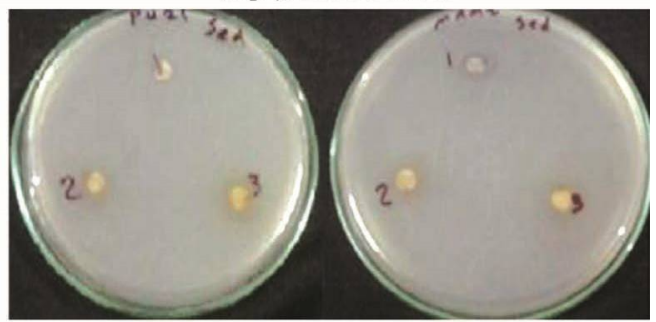

Pseudomonas aeruginosa

Fig. 1. Antibacterial activity of Myrtus communis and Ziziyphus spina-christi.

thuringiensis came in the last place $(15 \mathrm{~mm})$. Khalid et al. (2011) reported that the inhibitory effect of the Ziziyphus spina-christi leaves extract was observed up to the concentration of 50 $\mathrm{mg} / \mathrm{l}$, while Al-Mutairi et al. (2016) found that activity stopped at concentration of $32 \mathrm{mg} / \mathrm{l}$. Abdallah (2017) reported that the fruit extract of Ziziphus spina-christi has no antibacterial activity against Escherichia coli and Klebsiella pneumonia, whereas it showed moderate antibacterial activities against Staphylococcus epidermidis and Staphylococcus aureus.. According 
to Belmimoun et al. (2016) $14 \mathrm{~mm}$ or greater were considered as high antibacterial activity. The present results demonstrate that ethanolic extracts of Myrtus communis and Ziziyphus spina-christi have strong antibacterial activity. Cassia angustifolia extract showed moderate antibacterial activity against some tested strains, the inhibition zone diameter ranged between $8-12 \mathrm{~mm}$, but did not have any effect on other strains. These results are in agreement with the findings of Ahmed et al. (2016) and Bereksi et al. (2018). Singanboina et al. (2014) showed the remarkable inhibition of the Cassia angustifolia against bacterial growth. The bacterial survival assay is necessary to investigate the extracts toxic effects on the cells and demonstrate the intrinsic ability of a compound to cause cellular death because of damage to basic cellular functions.
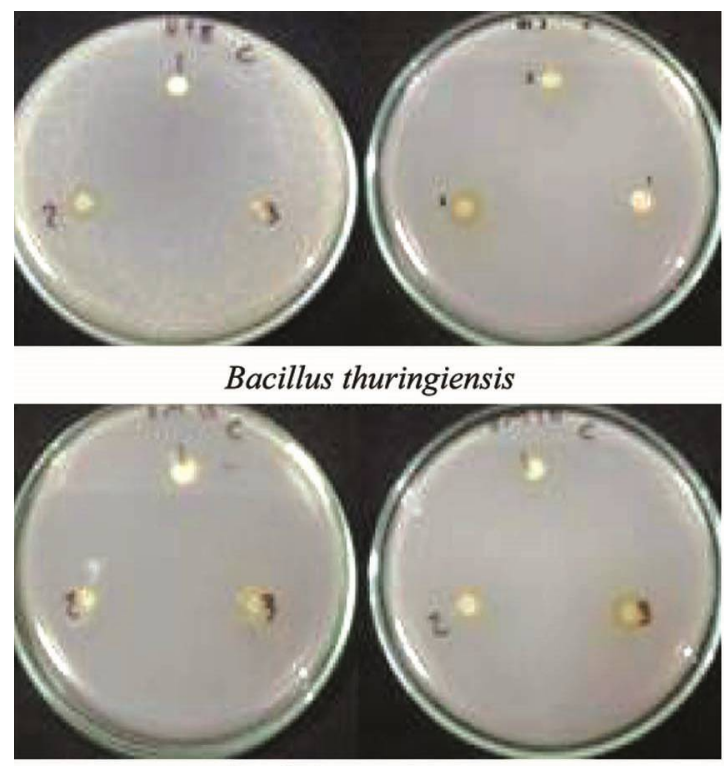

Staphylococcus aureus

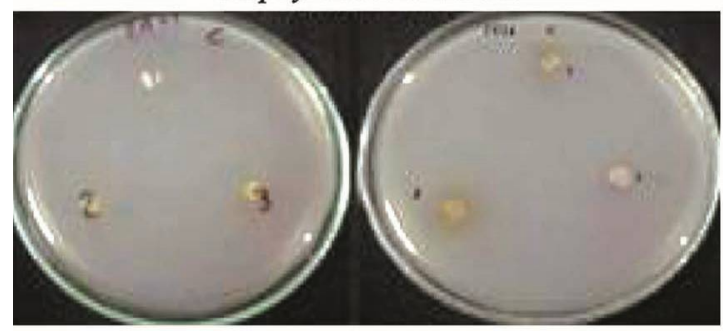

Pseudomonas aeruginosa

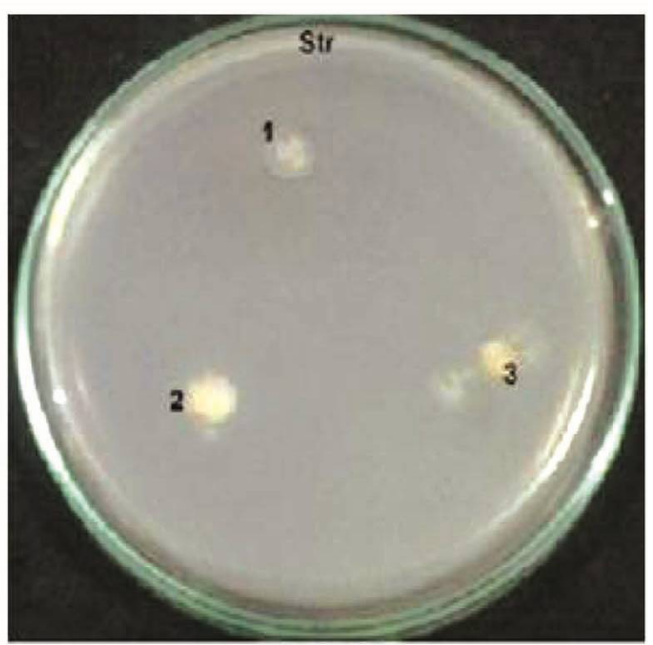

Streptomycin resistant strain as a control

Fig. 2. Antibacterial activity of Cassia angustifolia and streptomycin.

With regard to the extracts of antifungal activity, the results showed a similar pattern to that of antibacterial assay. The tested fungus, Rhodotorula spp. when treated with discs containing 30 $\mathrm{mg} / \mathrm{ml}$ of Myrtus communis and Ziziyphus spina-christi extracts showed inhibition of growth as indicated by diameter of the inhibition zones (18 and $16 \mathrm{~mm}$ respectively). However, Cassia angustifolia extract did not show any effect at all concentrations (Table 4). 
Table 4. Inhibition zone of ethanolic extracts of Myrtus communis, Ziziyphus spina-christi and Cassia angustifolia against Rhodotorula spp. fungus.

\begin{tabular}{lcc}
\hline Plant extract & $\begin{array}{c}\text { Concentration } \\
(\mathrm{mg} / \mathrm{ml})\end{array}$ & $\begin{array}{c}\text { Size of Inhibition zone } \\
(\mathrm{mm}) \pm \text { standard error }\end{array}$ \\
\hline Myrtus communis & 5 & 0 \\
& 15 & $10 \pm 0.23$ \\
Ziziyphus spina-christi & 30 & $18 \pm 0.40$ \\
& 5 & 0 \\
& 15 & $8 \pm 0.13$ \\
Cassia angustifolia & 30 & $16 \pm 0.72$ \\
& 5 & 0 \\
& 15 & 0 \\
\hline
\end{tabular}

Davariya and Vala (2011) recorded that Cassia occidentalis extract was active against some fungi while was not active against others. Mehrabani et al. (2013) showed that methanolic extracts of Myrtus communis had antifungal activity against Microsporum canis, Microsporum gypseum and Tricophyton mentagrophytes. Ads et al. (2017) demonstrated that Myrtus communis had antifungal effects against Aspergillus fumigate. The antibacteriophage assay was performed using F116 against Pseudomonas aeruginosa and R3 against Bacillus thuringiensis in the direct plaque assay which indicate the antiviral activity. The obtained results revealed that ethanolic extracts of Myrtus communis and Ziziyphus spina-christi showed antiviral activity against F116 and R3 bacteriophages (Table 5). Ziziyphus spina-christi showed total inhibition of phage viability at all used concentrations $(\mathrm{Pfu} / \mathrm{ml}=0)$, Myrtus communis showed no plaque formed at high concentrations $(15,30 \mathrm{mg} / \mathrm{ml})$, while at $5 \mathrm{mg} / \mathrm{ml}$ the Pfu/ml was $4.6 \times 10^{2}$ with F116. These results indicate that Ziziyphus spina-christi and Myrtus communis had strong antiviral activity. Cassia angustifolia extract had minimal effects on tested phages, Pfu/ml range was $1.3 \times 10^{7}-1.8 \times 10^{9}$. The results of the present study indicate that, Myrtus communis and Ziziyphus spina-christi extracts have strong antiviral agents against F116 and R3 bacteriophages, while Cassia angustifolia has moderate inactivation. Behravan et al. (2011) showed that Thymus transcaspicus essential oil had a moderate antiviral activity against phage CP51. Mohammed et al. (2013) demonstrated that anthraquinones isolated from Cassia roxburghii leaves have antiviral activity against influenza virus. The phytochemicals extracts act as antiviral by two mechanisms: one via their effect on viral particles before attachment to host cell and one after their effect on virus after entering the host cell. For example, polyphenols act by binding to the protein coat and thus repress adsorption of the virus. While flavonoids exhibit antiviral effects by inhibiting the RNA synthesis of viruses. They also inhibit replication enzymes of virus such as RT for HIV and RNA polymerase for influenza virus (Behravan et al. 2011).

Medicinal plants have flavonoids, tannins, alkaloids, polyphenolic components and saponins. The presence of these phytochemicals as bioactive components is responsible for its medicinal properties. Mehrabani et al. (2013) demonstrated that existence of flavonoids of M. communis leaves could be the cause of their important medicinal properties. Hussein et al. (2017) showed that alkaloid, phenolic and torpedoed compounds that were extracted from Myrtus Communis had antimicrobial activity against human gram-negative pathogenic bacteria. Al-Mutairi et al. (2016) showed that unsaturated fatty acids of Ziziyphus spina-christi were the major components $(83.5 \%)$ that are responsible for the antimicrobial activity of this plant. Qualitative phytochemical screening of different extracts of $C$. angustifolia by Ahmed et al. (2016) revealed the presence of 
alkaloids, steroids, flavonoids, saponins, terpenes, phenols, tannins, coumarins, terpenes, glycosides and anthraquinones which contribute to the antioxidant, antimicrobial and anticancer activities. Douhri et al. (2017) demonstrated that the antimicrobial activity may be attributed to tannin and polyphenolic compounds level in plants. This may lead to the damaging effect of these components on cell wall, proteins and DNA synthesis. Also, plant extracts and their components

Table 5. Effect of ethanolic extracts of Myrtus communis, Ziziyphus spina-christi and Cassia angustifolia on bateriophages viability.

\begin{tabular}{lccc}
\hline Plant extract & $\begin{array}{c}\text { Concentration } \\
(\mathrm{mg} / \mathrm{ml})\end{array}$ & \multicolumn{2}{c}{ Plaque forming unite (Pfu/ml) } \\
\hline \multirow{2}{*}{ Myrtus communis } & 5 & Phage F116 & Phage R3 \\
& 15 & 0 & 0 \\
& 30 & 0 & 0 \\
Ziziyphus spina-christi & 5 & 0 & 0 \\
& 15 & 0 & 0 \\
Cassia angustifolia & 30 & $1.9 \pm 0.44 \times 10^{7}$ & $1.8 \pm 0.21 \times 10^{9}$ \\
& 5 & $1.7 \pm 0.25 \times 10^{7}$ & $1.5 \pm 0.43 \times 10^{8}$ \\
Control (without extracts) & 15 & $1.3 \pm 0.12 \times 10^{7}$ & $1.2 \pm 0.23 \times 10^{8}$ \\
& 30 & $1.4 \pm 0.33 \times 10^{8}$ & $1.8 \pm 0.05 \times 10^{9}$ \\
\hline
\end{tabular}

are hydrophobic, enabling them to fractionate the lipids of the bacterial cell membrane, disturbing the cell structures and rendering them more permeable. Excessive exit of ions and critical molecules will lead to death (Hussein et al. 2017). Medicinal plants are considered good resources for producing antimicrobial agents that act as natural non-harmful alternatives to antibiotics in the treatment of antibiotic-resistant microorganisms.

\section{References}

Abdallah EM 2017. Antibacterial activity of fruit methanol extract of Ziziphus spina-christi from Sudan. Int. J. Curr. Microbiol. App. Sci. 6: 38-44.

Ads EN, Rajendrasozhan S, Hassan SI, Sharawy SM and Humaidi JR 2017. Phytochemical, antimicrobial and cytotoxic evaluation of Ziziphus spina christi (L.) stem bark. Biomedical Res. 28: 6646-6653.

Ahmed SI, Hayat MQ, Tahir M, Mansoor Q, Ismail M, Keck K and Bates RB 2016. Pharmacologically active flavonoids from the anticancer, antioxidant and antimicrobial extracts of Cassia angustifolia Vahl. BMC Complementary and Alternative Medicine 16: 460-468.

Al-Mutairi MH, Ali S, Aly SM. and Aldebasi Y 2016. Antibacterial activity of Sider (Ziziphus spina-christi), leaves extract against selected pathogenic bacteria. EJPMR 3: 138-144.

Alyousef AA, Al Akeel R, Alqasim A, Mohammed A, Mateen A and Syed R 2018. Evaluation of antibacterial activity of twenty-two medicinal plants traditionally used in Saudi Arabia against pathogenic bacteria. EC Microbiology 14: 108-112.

Amal AM, A. Khalil A and El-Beltagi HE S 2010. Antioxidant and antimicrobial properties of kaffmaryam (Anastatica hierochuntica) and doum palm (Hyphaene thebaica). Grasas Y Aceites 61: 67-75.

Behbahani BA, Yazdi FT, Noorbakhsh H, Riazi F, Jajarmi A and Yazdi FT 2016. Study of the antibacterial activity of methanolic and aqueous extracts of Myrtus communison pathogenic strains causing infection. Res. Med. Sci. 18: e5989. 
Behravan J, Ramezani M, Nobandegani EFand Gharaee ME 2011. Antiviral and antimicrobial activity of Thymus trascaspicus essetial oil. Pharmacology Online 1: 1190-1199.

Belmimoun A, Meddah B, Meddah AT and Sonnet P 2016. Antibacterial and antioxidant activities of the essential oils and phenolic extracts of Myrtus communis and zygophylum album from Algeria. Journal of Fundamental and Applied Sciences 8: 510-524.

Bereksi MS, Hassaine H, Bekhechi C and Abdelouahid DE 2018. Evaluation of antibacterial activity of some medicinal plants extracts commonly used in Algerian traditional medicine against some pathogenic bacteria. Pharmacogn J. 10: 507-512.

Davariya VS and Vala AK 2011. Antifungal activity of crude extracts of Cassia occidentalis. Int. J. Res. Phytochem. Pharmacol. 1: 36-38.

DeMarini D, Brooks H and Parkes D 1990. Induction of prophage lambda by chlorophenols. Environ. Mol. Mutagen 15: 1-9.

Douhri H, Raissouni I, Amajoud N, Belmehdi O, Benchakhtir M, Tazi S, Abrini J and Douhri B 2017. Antibacterial effect of ethanolic extracts of Moroccan plant against Escherichia coli. J. Mater. Environ. Sci. 8: 4408-4414.

Hussein HJ, Al-Khafaji NMS, Al-Mamoori AH, Juaifer WAK, Al-Marzoqi AH and Al-Zobiady RA 2017. Antimicrobial effect of the crude phenolic, alkaloid and terpenoid compounds extracts of Myrtus communis $L$. against human gram-negative pathogenic bacteria. Journal of Global Pharma Technology 8:130-133.

Jerbi A, Abdennabi R, Gharsallah N, Flamini G and Kammoun M 2016. Essential oil composition, freeradical-scavenging and antibacterial effect from leaves of Myrtus communisin tunisia. RJPBCS 7: 621.

Khalid KA, Aziz FM and Abdalah ME 2011. A study of antibacterial activity of Sider (Zizyphus spina christi $\mathrm{L}$ ) on bacterial pathogens isolated from skin infections. AJPS 9: 1 .

Mehrabani M, Kazemi A, Mousavi SAA, Rezaifar M, Alikhah H, Nosky A 2013. Evaluation of antifungal activities of Myrtus communis L. by bioautography method. Jundishapur J. Microbiol. 6: e8316.

Mohammed MMD, EL-Souda SS, EL-Hallouty SM and Kobayashi N 2013. Antiviral and cytotoxic activities of anthraquinones isolated from Cassia roxburghii Linn. leaves. Herla Polonica, p. 59.

Nkafamiya M, Shagal H and Haruna M 2013. Potential of Ziziphus spina-christi seed ethanolic extract on inhibition of microbial growth. Academia Journal of Biotechnology 1: 053-056.

Romha G, Admasu B, Gebrekidan TH, Aleme H and Gebru G 2018. Antibacterial activities of five medicinal plants in Ethiopia against some human and animal pathogens. Evidence-Based Complementary and Alternative Medicine 2018: 1-11.

Singanboina K, Chinna V, Ratnampally SK and Rao KK 2014. Antibacterial activity of Cassia angustifolia (Vahl.) leaf extracts grown in three different soil treatments. IJPLCP 5: 3631-3633

Siddiqui AH, Tabrezand S, and Ahmad M 2011. Short-term in vitro and in vivo genotoxicity testing systems for some water bodies of Northern India. Environ. Monit. Assess. 180: 87-95.

Silva CR, Vieira PM, Santos SC and Chen LC 2012. Assessment of Duguetia furfuracea genotoxic and cytotoxic activity in bacteria and mice. Anais da Academia Brasileira de Ciências 84: 149-156

Taheri A, Seyfan A, Jalalinezhad S and Nasery F 2013. Antibacterial effect of Myrtus communis hydroalcoholic extract on pathogenic bacteria. ZJRMS 15: 19-24.

Touaibia M 2015. Antimicrobial activity of the essential oil of Myrtus communis L. berries growing wild in Algeria. J. Fundam. Appl. Sci. 7: 150-162.

(Manuscript received on 11 February, 2019; revised on 20 October, 2019) 